\title{
Simulations of the Effect of Currently Used Grenade Harpoons for the Killing of Whales Using a Pig-Model
}

\author{
By A.S. Blix, L.P. Folkow and D.G. Sørlie \\ Department of Arctic Biology and Institute of Medical Biology, University of Tromsø, Norway.
}

\begin{abstract}
Blix AS, Folkow LP, Sørlie DG: Simulations of the effect of currently used grenade harpoons for the killing of whales using a pig-model. Acta vet.scand. 2000, 41, 237242. - Physical model experiments, as well as simulations of the effects of grenade harpooning on anaesthetized pigs fully immersed in water suggest that the shock effect of the blast from the currently used grenades is relatively minor. Also the animals are not stunned to death, but loose consciousness and subsequently die from hemorrhage. Survival time is therefore very short if the animals are hit in the thorax, and is likely to be further reduced if the charge which is currently used is increased, or, even better, if shrapnel (fragment scattering) grenades are used instead of blast grenades.
\end{abstract}

minke whale; bowhead whale; Balaewoptera acutorostrata; Balaena mysticetus; humane killing.

\section{Introduction}

Bowhead (Balaena mysticetus) and minke whale (Balaenoptera acutorostrata) are the only large whales currently harvested in any appreciable numbers. The bowhead, which is a large right whale that may reach $20 \mathrm{~m}$ in length and weigh up to about 70 tons, is mainly hunted by Alaskan Eskimos. The weapons used by the Eskimos consist of 2 types of grenade launchers - the "Darting Gun" and the "Shoulder Gun". The darting gun is in principle a handthrown lance, while the shoulder gun in principle is a heavily modified shot-gun. The grenades for the 2 launchers are virtually identical and contain $52 \mathrm{~g}$ of black powder (Øen 1995a). The minke whale, the smallest of the fin whales, reaching a length of about $9 \mathrm{~m}$ and a weight of up to 9 tons, is mainly hunted by Norwegians and the Japanese. The weapon used is a black powder cannon which delivers a steel harpoon with a grenade containing $22 \mathrm{~g}$ of the supersonic explosive penthrite (Øen 1995b).

In the Norwegian hunt about $50 \%$ of minke whales die instantly while some are reported to live for several minutes after being hit (Øen 1995b). In the Alaskan hunt, however, very few whales die instantly; several do, in fact, live for hours, and about $30 \%$ are hit and lost (Øen 1995a).

The purpose of the present study was to elucidate why so many whales live so long after being hit by grenade harpoons, and to suggest ways to improve the currently used methods. In so doing we have carried out model experiments to reveal some physical features of blast under water, which are hard to simulate mathematically, and we have recorded the effects of blasts in 2 different parts of the body of fully anaesthetized pigs, which were completely submerged in water.

\section{Materials and methods}

Physical model experiments

The pigs used in this study weighed approximately $50 \mathrm{~kg}$ and had a lung volume of approx- 
imately 31 (Stahl 1967). The standard grenade for minke whales, which on average weigh about $4000 \mathrm{~kg}$ and have a lung volume of $280 \mathrm{l}$ (Folkow \& Blix 1992), contains $22 \mathrm{~g}$ of penthrite (Øen 1995b), which produces about 1801 of gas when set off. For the purpose of proper scaling, an electric fuse, containing $0.35 \mathrm{~g}$ of penthrite, which produces approximately 31 of gas, was therefore developed and used as charge both in our physical model experiments and in our in vivo experiments.

The charge was used for 5 experiments in an 8301 water tank, which measured $60 \times 185 \times 75$ $\mathrm{cm}$. First, it was suspended and set off in midwater. The pressure it generated was measured at a distance of $1 \mathrm{~m}$ by use of a Model 111 A22 piezoelectric pressure transducer connected via a model 480E09 ICP signal conditioner (both PCB Piezotronics, Inc., NY, USA) to a digital oscilloscope (Model 54600 A, Hewlett Packard, CA, USA). Second, to test the effect of a volume of air, such as that of the lung, between the blast and the brain, an airfilled thin-walled rubber balloon with a volume of 31 was suspended under water, midway between the charge and the transducer, which again were separated by $1 \mathrm{~m}$, and the charge set off. Third, to test effect of a blast inside a volume of air, such as that of the lung, the charge was set off at the centre inside a 31 airfilled thin-walled rubber balloon which was suspended under water, and the pressure recorded at a distance of 1 $\mathrm{m}$. Fourth, to test the effect of a solid structure, such as the skull, on the propagation of the shock-wave from the blast through the body, the pressure transducer was mounted inside a 1.91 water-filled rigid spherical (PVC) plastic (fishing-net) float (Danfender 6", Denmark) with a wall thickness of $3 \mathrm{~mm}$, suspended under water, and the charge set off at a distance of $1 \mathrm{~m}$. Fifth, this was further tested by mounting of the pressure transducer to measure intracranial pressure in an excised, but otherwise intact pig head, as described below. The head was then suspended under water, and the charge set off at a distance of $1 \mathrm{~m}$. These experiments were all repeated twice.

\section{In vivo experiments}

To further elucidate the effects of a grenade in a live animal, $50 \mathrm{~kg}$ pigs were fully anaesthetized with Ketalar $(20 \mathrm{mg} / \mathrm{kg})+$ Dormicum $(0.25 \mathrm{mg} / \mathrm{kg})$, i.m., followed by Leptanal $(6$ $\mathrm{ug} / \mathrm{kg}$ ), i.v., and maintained by Pentobarbital $(25 \mathrm{mg} / \mathrm{kg} / \mathrm{hr})$, i.v..

The animals were thereafter tracheostomized, and a catheter was put into the brachial artery and connected to a pressure transducer (Abbot Model F978-54, Abbot Ireland, Ltd., Ireland) connected to a Gould TA 4000 recorder (Gould Electronics, $\mathrm{OH}, \mathrm{USA})$.

A hole $(\emptyset=7 \mathrm{~mm})$ was drilled through the skull of the animal, care being taken to avoid damage to the dura mater. The hole was threaded with a $10 \mathrm{~mm}$ thread tap and a $15 \mathrm{~mm}$ long brass pipe with outside threads was screwed into the hole. The brass pipe was also threaded on the inside so the Model 111A22 piezoelectric pressure transducer, which was the same as the one used for the physical model tests, could be screwed until its membrane was flush with the dura mater. It was then connected to an oscilloscope, as described above for the physical model experiments, for measurements of intracranial pressure.

The charge was carefully introduced into the thorax in a silicone tube through a small right side thoracostomy, or into the abdomen through a small hole in the abdominal wall. The silicone tubes were subsequently removed and the entrance hole securely closed with running sutures around the electrical wires from the fuse. In 2 animals a glass bubble-trap was additionally surgically inserted into both carotid arteries.

The animals were equipped with loads on all 4 
feet and placed, fully submerged, in the tank described above, at a water temperature of approximately $30^{\circ} \mathrm{C}$. Due to the positive bouyancy of the animal it maintained a "normal" standing posture on the bottom of the tank. In this position the animal was ventilated through the tracheal tube until $10 \mathrm{sec}$ before the charge was set off, at which time the tube had been closed with a clamp at end of inspiration to simulate "diving".

Four experiments were done in duplicate to test the effect of the magnitude and location of the blast: One charge was set off in the abdomen; one charge was set off in the thorax; a double charge was set off in the thorax; a double charge was set off in the abdomen; and a double charge was set off in the thorax with the bubble trap inserted into the carotid arteries. In all these experiments intracranial and central arterial pressures were recorded.

These experiments were carried out under permit from the Norwegian Committee for Ethics in Animal Experimentation.

After the blast the animals were removed from the water and autopsied. Samples were taken from brain tissue, fixed in buffered formaldehyde and examined histologically for hemorrhages and air emboli at the Department of Pathology at the University Clinic of Tromsø.

\section{Results}

\section{Physical model experiments}

When the charge was set off in water, it generated a peak pressure of $30 \mathrm{~atm}$ in the water at a distance of $1 \mathrm{~m}$ (Fig. 1). When the 31 airfilled balloon was placed midway between the charge and the transducer the pressure which was recorded in the water was reduced to 9 atm at a distance of $1 \mathrm{~m}$ from the charge. When the charge was set off inside the 31 airfilled balloon the pressure which was recorded in the water at a distance of $1 \mathrm{~m}$ was $2 \mathrm{~atm}$. When the charge was set off in water the pressure it generated in-

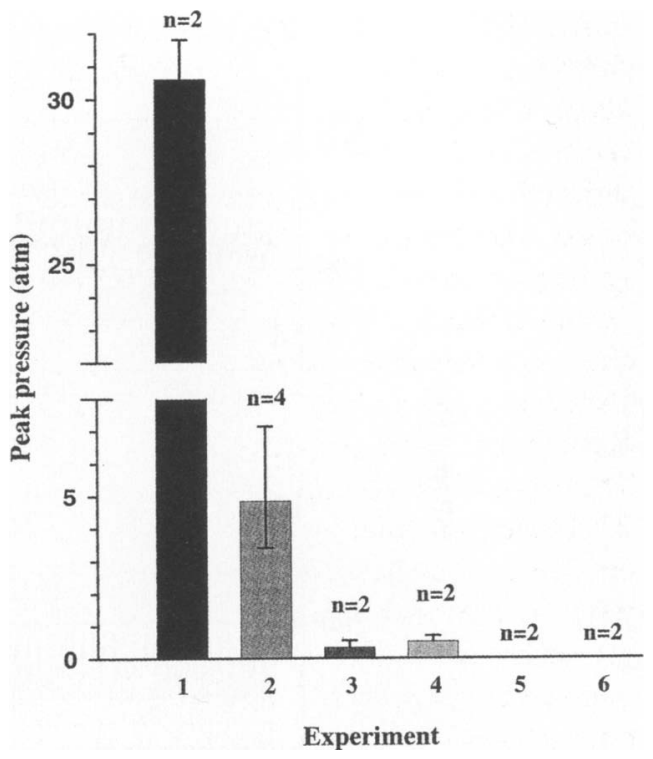

Figure 1. Mean peak pressures \pm ranges (atm) in 6 different blast experiments:

1. Peak pressure recorded after discharge of one standard charge in water at $1 \mathrm{~m}$ distance from the pressure tansducer $(\mathrm{n}=2)$.

2. Peak intracranial pressure recorded after discharge of a double standard charge in the thorax of pigs suspended in water $(n=4)$.

3. Peak intracranial pressure recorded after discharge of one standard charge in the thorax of pigs suspended in water $(\mathrm{n}=2)$.

4. Peak intracranial pressure recorded in excised pig heads after discharge of one standard charge in water at $1 \mathrm{~m}$ distance from the head $(\mathrm{n}=2)$.

5. Peak intracranial pressure recorded after discharge of a double charge in the abdomen of pigs suspended in water $(\mathrm{n}=2)$; No pressure change detected.

6. Peak intracranial pressure recorded after discharge of one standard charge in the abdomen of pigs suspended in water $(n=2)$; No pressure change detected.

side the water filled plastic float, at a distance of $1 \mathrm{~m}$ from the charge, was again $2 \mathrm{~atm}$, while the pressure recorded inside the excised head was only $0.5 \mathrm{~atm}$ at a distance of $1 \mathrm{~m}$ from the charge. 


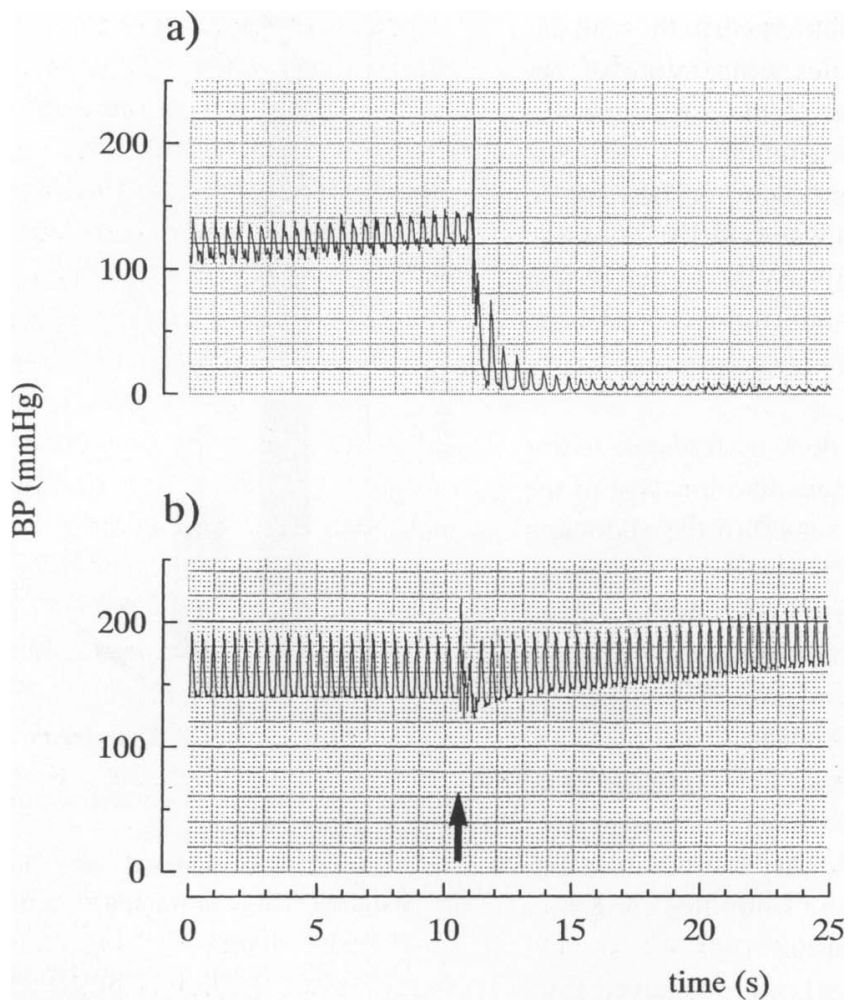

Figure 2. Typical recordings of the central aortic blood pressure (BP) of two $50 \mathrm{~kg}$ anaesthetized pigs, fully submerged in water, in response to the blast (arrow) from a $0.35 \mathrm{~g}$ penthrite charge ; a) in the thorax of one of the animals, and b) deep in the abdomen of another. Time in seconds (s).

\section{In vivo experiments}

When single charges were set off in the abdomen of the animal, there was no recordable increase in the intracranial pressure (Fig. 1) and both heart rate and blood pressure were maintained (Fig. 2b). The animals were killed after $10 \mathrm{~min}$ by an overdose of Pentobarbital. This was also the case when double charges were set off in the abdomen (Fig. 1), except in one case where the abdominal aorta ruptured by the blast and blood pressure dropped precipitously and the heart stopped. Tissue damage was in all other cases limited and no dramatic bleeding occurred.
When single charges were set off inside the thorax, arterial blood pressure always dropped precipitously and the heart invariably stopped immediately (Fig. 2a). However, the blasts only produced an increase in intracranial peak pressure of less than $0.5 \mathrm{~atm}$ (Fig. 1). When double charges were set off inside the thorax the changes in arterial blood pressure and heart rate were the same, but the blast now produced an increase in intracranial peak pressure of $5 \pm 1$ (SD) $\operatorname{atm}(n=4)$, (Fig. 1). In 2 of these experiments the bubble trap was inserted into both carotid arteries, but no bubbles were observed in the trap after the blast. 
In all cases where the blast occurred within the thorax one of the lungs was always damaged to some extent and subpleural blebs as well as alveolar hemorrages were prominent. Changes in the other lung, which was not directly affected by the blast, were much less evident.

Histological examination of the brains of the animals revealed no cerebral air emboli or hemorrhages.

\section{Discussion}

Our in vivo experiments clearly demonstrate the importance of the location of the blast, in that animals hit in the thorax suffer dramatic hemorrhage with loss of blood pressure and cardiac arrest (Fig. 2 a), while animals which are hit in the abdomen are much less affected (Fig. 2 b). A hit in the muscles or in the abdomen, will have even much less effect in diving mammals, like whales, which respond to diving with profound peripheral vasoconstriction (e.g. Blix \& Folkow 1983), and hence may reduce loss of blood for prolonged periods while under water.

The importance of the location of the hit, and consequently the effect of the blast is already well documented in an excellent and comprehensive field study by Øen (1995b). He clearly demonstrated that hits in the thorax and in the upper abdomen (close to the aorta) result in very short survival times, while hits in the lower abdomen, in the tail, and even in the head (outside the brain) result in much longer survival times. Our physical model experiments make it quite clear that an air space, such as that of the lungs, will reduce the shock wave which reaches the brain when the blast originates outside the thorax, and, in fact, even when it occurs inside the lung. Our in vivo experiments, on the other hand, show that intracranial pressure increases substantially when the gas volume which is produced by the grenade exceeds the gas volume in the lungs (Fig. 1).
Our physical model experiments also clearly indicates that the pressure wave is reflected by hard objects, such as the skull, and that the shock wave which reaches the brain therefore is much reduced (Fig. 1). This is also supported by the lack of apparent pathological changes in the brains of our pigs, although diffuse axonal injury cannot be ruled out, since the disruption of the axons does not seem to occur until some time after the original injury (e.g. Adams et al. 1991). In fact, field observations clearly indicate that the animals which are hit in the thorax and die within a very short time appear to become completely paralysed upon impact (personal observations), indicative of spinal shock and possible diffuse axonal injury.

According to Sharpnack et al. (1991) alveolovenous fistula resulting in air emboli in heart and brain tissue are the causes of most deaths from blast in water. However, all blast effect studies thus far have only dealt with blasts originating outside a subject which in most cases had access to air. In cases where the blast occurs inside the thorax of the animal, such as in whales, where our in vivo studies have shown that blood pressure and heart rate drop instantly, air emboli, even if they are produced in the lungs, are less likely to be distributed to other organs. Accordingly, when we inserted bubbletraps into the carotid arteries of our pigs, no bubbles were discovered, nor were air emboli found in the brain upon histological examination, even after high pressure intrathoracic blasts. It follows, that the creation of air emboli is even less likely when the whale is hit outside the thorax.

Moreover, effect of blast in an animal completely immersed in water will, to a great extent, depend on the gas volume produced by the explosion, and it will increase dramatically when it exceeds the volume in the lungs. The currently used grenades for minke whales produce a gas volume of about $180 \mathrm{l}$, which is less 
than the 2801 lung volume of an average-sized $4000 \mathrm{~kg}$ minke whale (Folkow \& Blix 1992). The blackpowder charges currently used in the bowhead hunt in Alaska only produce a gas volume of about $150 \mathrm{l}$, while the whales may weigh as much as 70 tons and probably have lung volumes in excess of 10001 (Stahl 1967). Not surprisingly, therefore, up to 24 grenades have been used to kill one whale, while the average is 5 , and survival times of several hours after the first strike are not uncommon (Øen 1995a). In conclusion, we suggest that minke whales, and, certainly, bowhead whales, are not stunned to death by the currently used grenade harpoons, but that they loose consciousness and subsequently die due to the hemorrhage produced by the blast. It follows, that animals that are hit in the thorax are likely to die instantaneously, while those that are hit elsewhere (outside the central nervous system and the abdominal aorta) will survive much longer.

Aside from the obvious, that whales, like all other game, should only be shot in the thorax, it is therefore our belief that survival time, both in the minke whale and particularly in the bowhead whale hunt, would be much reduced if the size of the charges is increased so that the gas volume produced by the blast is well in excess of the lung volume of the animals, or even better, if the currently used blast grenades were replaced by shrapnel (fragment scattering) grenades.

\section{Acknowledgements}

We thank Mr. A.M. Oddan of the Norwegian Defence Research Establishment for constructive discussions and advice throughout this study, and Prof. Sigurd Lindal of the Department of Pathology, Institute of Medical Biology, University of Troms $ø$, for the histological examinations of brain tissue.

\section{References}

Adams JH, Graham DI, Gennarelli TA, Maxwell WL: Diffuse axonal injury in non-missile head injury. J. Neurol. Neurosurg. Psychiat. 1991, 54, 481483.

Blix AS, Folkow B: Cardiovascular adjustments to diving in mammals and birds. In: Shepard JT, Abboud FM (eds.): Handbook of Physiology. The Cardiovascular System. Vol. III(2). Am. Physiol. Soc.,Bethesda, USA, 1983, pp 917-945.

Folkow LP, Blix AS: Metabolic rates of minke whales in cold water. Acta Physiol. Scand. 1992, 146, 141-150.

Sharpnack DD, Johnson AJ, Phillips YY: The pathology of primary blast injury. In: Bellamy RF, Zajtchuk R (eds.): Textbook of Military Medicine, Part I, vol.5. Office of the Surgeon General, US Army, Washington DC, pp. 271-294.

Stahl WR: Scaling of respiration variables in mammals. J. Appl. Physiol. 1967, 22, 453-460.

Øen EO: Effectiveness of a new penthrite grenade for the Alaskan eskimo hunt for bowhead whales compared with the traditional black powder grenade. Arctic 1995a, 48, 177-185.

Øen EO: A Norwegian penthrite grenade for minke whales : Hunting trials with prototypes and results from the hunt in 1984, 1985 and 1986. Acta Vet. Scand., 1995b, 36, 111-121.

\begin{abstract}
Sammanfattning
Simuleringer av effekten av granatharpuner for avlivning av hval ved bruk av en grise-modell.

Fysiske modelleksperimenter og simulering av effekten av granatharpuner i anesteserte griser, som var helt nedsenket $\mathrm{i}$ vann, indikerer at sjokkeffekten av eksplosjonen fra de for tiden brukte granatene er relativt liten, og det er lite som tyder på at dyrene vanligvis dør av eksplosjonssjokket. Det er derimot trolig at dyrene mister bevisstheten og derefter dør som følge av blodtab. Overlevelsestiden er derfor svært kort hvis dyrene blir truffet i brystet, og vil sannsynligvis bli ytterligere redusert hvis ladningen $\mathrm{i}$ granaten økes, eller ennu bedre, om man tar i bruk splintgranater isteden for de nu brukte sjokkgranater.
\end{abstract}

(Received May 27,2000, accepted June 12, 2000).

Reprints may be obtained from: A.S. Blix, Department of Arctic Biology University of Tromsø N-9037 Tromsø, Norway. E-mail: asblix@fagmed.uit.no, tel: +47 776 44867, fax: +47 77645750. 